\title{
Biological Control of Coleopteran Pests
}

\author{
Purti*, Rinku, R. S. Jaglan and Krishna Rolania
}

Department of Entomology, CCS Haryana Agricultural University, Hisar, Haryana (125 004), India

\author{
Corresponding Author \\ Purti \\ e-mail:purti5678@gmail.com
}

\author{
Article History \\ Article ID: $3 \mathrm{C0249}$ \\ Received in $24^{\text {th }}$ September, 2017 \\ Received in revised form $16^{\text {th }}$ April, 2018 \\ Accepted in final form $26^{\text {th }}$ May, 2018
}

\begin{abstract}
Coleopteran pests having the modified forewings which serves as protective covers for the membranous hind wings and commonly called as beetle. Most of them are important pest of agriculture, forestry, fruit trees and stored grain while only a few species are considered to be beneficial. Man has probably been plagued by insect pests ever since he began to grow crops and rear animals. Worsened by the ability of these pests to emerge and re-emerge, man, his crops, livestock as well as his socio-economic status stand on the threshold of destruction. Challenged by this danger and frustrated by the demerits of chemical pest control, man began to explore the use of identified natural enemies as agents of bio control to manage potentially damaging population below levels that they can cause economic injury. Biologically we can control the coleopteran pests with the help of several predators, parasitoids and entomopathogens, ants, mites and mammals. Tree creepers, chickadees, nuthatches, flycatchers, swallows, tanagers, finches, thrushes, jays, wrens, kinglets, and warblers are the predatory birds that feed on the different species of beetles. Diabrotica sp., Solenopsis geminate and Pheidole megacephala are the predatory ants that removed $80 \%$ of exposed Diabrotica eggs. Iponemus sp., Pyemotes giganticus and Pymotes dryas are the predatory mites that are used in controlling the pine and bark beetles. Similarly, entomopathogens are also play an important role in controlling the coleopteran pests and it includes fungi, viruses, bacteria and nematodes.
\end{abstract}

Keywords: Beetles, Entomopathogens, predator, bacteria, fungi, virus

\section{Introduction}

The name Coleoptera, derived from the Greek words "koleos" meaning sheath and "ptera" meaning wings given to the group by Aristotle, refers to the modified front wings which serve as protective covers for the membranous hind wings. Coleopterans also called beetles and beetles are the flying insects belonging to the order 'Coleoptera' which are represented by $3,60,000$ species and 178 families worldwide and constitute the largest order of insects. It includes $40 \%$ of all insects and nearly $30 \%$ of all animal species. It means, about one third of the described animal species may be beetles. Thus, it is considered to be the largest collection of living organisms and believed to be in existence since 270 million years ago. Beetle family is very diverse and wide. Found in almost every part of the world, they are the most common insects thriving in a varied range of habitats except polar and marine regions. The food habits also differ in each and every species, depending on their habitat. Some feed on plants and leaves, whereas some are carnivorous; they catch insects or invertebrates to eat. There are also other types like beetles feeding on fungus, pollens, crustacean and other insects. Most of them are important pest of agriculture, forestry, fruit trees and horticulture, while only a few species are considered to be beneficial.

\section{Classification}

Coleoptera is divided into four sub-orders; Adephaga, Archostemata, Polyphaga and Myxophaga. But only two of these, Aedephaga and Polyphaga include common families.

\subsection{Adephaga}

It is the first sub-order and carnivorous in nature. The most abundant families in this order are the Carabidae and Cicindelidae which includes the ground beetle and tiger beetle, respectively. The carabidae live on the soil surface, ground or ant nests and plants; they feed on insects, spiders, or mollusks. Most adults have phototaxis and hip glands of adults can release defensive substances such as formic acid or $p$-benzoquinone. Some of them are phytophagous, damaging cereals, strawberries and potatoes.

\subsection{Archostemata}

It is the second sub-order which lives under bark. It is the smallest sub-order placed in the Coleoptera order that has only five families with less than fifty identified species. 
The family included in this sub-order are Crowsoniellidae, micromalthidae, Ommatidae, Cupedidae and Jurodidae.

\subsection{Polyphaga}

It is the largest sub-order, containing $85 \%$ of known species, many of them are phytophagous. It consists mainly of the families Scarabaeidae, Curculionidae, Elateridae, Bruchidae, Chrysomelidae, Tenebrionidae, Cerambycidae, Buprestidae, Coccinellidae and Canthridae. The major damage caused by members of these families is as follows: some Scarabaeidae and Chrysomelidae are critical pests in agriculture and forestry; some Elateridae live under the soil and are important pests of crops; some Buprestidae and Cerambycidae eat wood and cause the loss of precious timber.

\subsection{Myxophaga}

Myxophaga sub-order is the second smallest group of Coleoptera order, first being Archostemata. This sub-order consists of just four families comprising 65 species of tiny beetles. The beetles of this sub-order are either semi-aquatic or aquatic in nature and associated with hygropetric habitats, drift material, or interstitial habitats among sand grains.

\section{Economic Importance}

Many beetles are regarded as major pests of agricultural plants and stored products. They attack all parts of living plants as well as processed fibers, grains, and wood products. Scavengers and wood boring beetles are useful as decomposers and recyclers of organic nutrients. Predatory species, such as lady beetles, are important biological control agents of aphids and scale insects. The major damage caused by members of these families is as follows: some Scarabaeidae and Chrysomelidae are critical pests in agriculture and forestry; some Elateridae live under the soil and are important pests of crops; some Buprestidae and Cerambycidae eat wood and cause the loss of precious timber.

In addition, some Bruchidae endanger the growth of the leguminous plants. Longhorn beetles are the most dangerous pest, they are phytophagous and most of them damage woody plants, including pine, cypress, willow, elm, citrus, apples, peaches and tea. Some coleopterans damage crops such as cotton, wheat, corn, sorghum, sugarcane and hemp, while others damage wood, construction, housing and furniture. They are important pest in forestry fields, crop cultivation and construction timber. In 1957, people found that the longhorn beetles destroyed lead sheets of telephone cables, resulting in the exposure of internal wires. They are also harmful to timber and dry goods. Books stored in bookstore were invaded by a variety of long horn beetle larvae and then dug a tunnel through five books. Therefore, the damage done by long horn beetle is very severe, especially for fruit trees and forests, and they are an extremely serious threat to human possessions. In the 1990s, it was reported that species Echinocnemus squameus (Coleoptera: Anthribidae) from the sub-order
Rhyncophora (now in family Curculionidae) seriously damaged rapeseed, wheat and cotton crops and is one of the major pests in paddy fields (Tan, 1992). The adults ruins leaves and the larvae ruins roots, causing serious hazards. Some individuals of Anthribidae are poisonous to the rice weevil, Sitophilus granaries (Coleoptera: Curculionidae) is another agricultural pest that damage a wide variety of crops ranging from cotton, hemp and cereals to sugar beet, melon, corn, peanut, soybean, sunflower, sorghum, tobacco and seedlings of fruit trees. The adults feed on the cotyledons, shoots and leaves of cotton and other newly sprouted seedlings. These insects often cluster together while they eat the leaves and bite tops off of stems; this clustering results in a circle or semi-circle of notches on one leaf.

\section{Biological Control of Coleopteran Pests}

Biological control may be defined as the action of predators, parasitoids, pathogens and antagonists or competitor populations to suppress a pest population, making it less abundant and less damaging than it would otherwise be (Eilenberg et al., 2001). Biological control of coleopteran pests is a method that uses an organism to deal with pests. It includes means such as the use of predators, parasitoids and pathogens (it includes bacteria, fungi, viruses and nematodes) that can reduce coleopteran pest populations. Its greatest advantage is that it does not pollute the environment.

\subsection{Predators}

Predators are characterized as follows:

- They are usually larger than their prey;

- They may be predaceous in either the immature stage, the adult stage, or both;

- They eat many prey during the course of their life;

- They are generally fairly mobile so that they can find or catch their prey; and

- Most of the species tend to have a fairly broad host range. The main predators of coleopteran insects are birds, ants, mites, predatory insects and mammals.

\subsubsection{Birds}

Birds belong to the class Aves. Birds are one of the most important biological control agents. Birds in 11 families have been recorded as preying on beetles, primarily during the short period of beetle emergence, flight, and attack on trees. However, since any mortality agent that acts on the preovipositing female beetle is proportionally more important than one which acts on any of the earlier brood stages, the "in-flight" mortality affected by these birds is probably significant (Blackman, 1931).

\subsubsection{Woodpackers}

Woodpeckers belong to the family picidae and are thought to be one of the most important biotic mortality agents of bark beetles (Dahsten, 1982). They have been most studied as predators of species of Dendroctonus, especially of $D$. 
rufipennis (Kirby) (spruce beetle), D. brevicomis (LeConte) (western pine beetle), D. ponderosae (Hopkins) (mountain pine beetle) and $D$. frontalis (Zimmermann) (southern pine beetle). Woodpeckers, by their mode of searching for bark beetle and other subcortical prey on infested trees, create the most conspicuous evidence of predation. All the outer bark and sometimes even the inner bark may be stripped from infested portions of bark beetle infested trees. Besides consuming bark beetle brood, woodpeckers also indirectly kill the insects by dislodging them from the tree and reducing the survival rate of insects remaining on the tree (desiccation, increased parasitism and predation) (Otvos, 1979).

A number of recommendations have been made with regard to enhancement of woodpecker populations, the most common being the provision of adequate numbers of snags suitable as nesting sites (Evans et al., 1979). Snag management may be the cheapest option, because it involves the modification of existing forestry practices and use of existing natural nesting sites.

Woodpecker food supplies may be enhanced by girdling some trees to increase populations of secondary stem insects, by culturing and dispersing other insects attractive to woodpeckers (Koplin, 1972), and by "high-stumping" during cutting operations to provide additional feeding sites (termites and carpenter ants).

\subsubsection{Red-winged blackbird}

The Red-winged blackbird, Agelaius phoeniceus L. (Passeriformes: Icteridae) frequently preys on corn rootworm beetles, Diabrotica longicornis (Coleoptera: chrysomelidae) in maize in Canada (Bllinger and Caslick, 1985).

\subsubsection{Perching birds}

These birds Included tree creepers, chickadees, nuthatches, flycatchers, swallows, tanagers, finches, thrushes, jays, wrens, kinglets, and warblers (Baldwin, 1968; Dahlsten, 1982; Otvos, 1969; Stallcup, 1963). Theobald in 1911 listed flycatchers, finches, starlings, several different warblers and tits as being predatory on vine weevil in the UK. Being general insectivores, these birds probably also consume insect predators and parasitoids of bark beetles (Otvos, 1979) and other beetles. This impact, which has not been assessed, must be balanced against the bird's consumption of bark beetles. Thus, at this stage the total impact of bird predation is not known.

\subsubsection{Predatory ants}

Ants are important predators of arthropods in many habitats and geographical regions, helping to control insect pest such as Diabrotica sp. (Paulson and Akre, 1992). In field experiment Costa Rica, Solenopsis geminate (Fabricius) and Pheidole megacephala (Hymenoptera: Formicidae) removed $80 \%$ of exposed Diabrotica eggs within 3 days (Risch, 1981). As common predators in agricultural settings worldwide, ants are quick to exploit coleopteran prey. In Cuba, the myrmicine ants, Pheidole megacephala (Fabricius) and Tetramorium guinense (Nylander) have been used as biological control agents against banana weevils (Castenieras and Ponse, 1991).

Myopopone, Pheidole, Pochycondyla, and Monomorium established their colonies inside corms or pseudostems of banana plants, while Anoplolepis gracilipes, Camponotus (Tanaemyrmex) sp., Diacamma rugosum, Odontomachus rixosus, and Pseudolasius sp. colonies were found in pseudostem leaf sheaths or in leaf trash at the base of mats. Myopopone castanea was directly observed attacking and removing banana weevil larvae from pseudostem and corm galleries.

\subsubsection{Mites}

Mites constitute a very diverse group of organisms, occupying a wide variety of habitats. Species in about 60 families have been recorded as associates of bark beetles and other beetles; many of these are probably incidental associations, since many mite species occupy the bark habitat of healthy trees. Mites that feed on bark beetle brood have been variously designated as parasitic (Kinn, 1971; Lindquist, 1969), predacious (Dahsten, 1982; Moser, 1975), or both (Mills, 1983).

\subsubsection{Iponemus $s p$.}

This species of mites belong to the family Tarsonemidae and order Acarina. Species of Ips (Lindquist, 1969), probably phoretic on all scolytids and atleast one tenebrionid beetle associate of bark beetles (Moser, 1981). Iponemus sp. feed and effective only on eggs of pine beetle (Moser et al., 1981).

\subsubsection{Pyemotes giganticus}

All life stages except the adult of bark beetles are preyed upon by this mite and feed on eggs, larvae and pupae. This mite contains venom which kills the host even though no feeding may occur (Moser et al., 1981). The impact of mite predation on bark beetle populations has been assessed only rarely. Estimation of mortality due to mite predation range from less than $1 \%$ to more than $90 \%$ (Lindquist, 1969). P. giganticus from western North American bark beetles as a predator of the southern pine beetle. The mite readily rode the southern pine beetle and other bark beetles.

\subsubsection{Pymotes dryas}

Moser and co-workers in 1981 assessed Pyemotes dryas (Vitzthum) from Poland as a predator of the southern pine beetle. Although this species is phoretic on a wide range of European bark beetles that attack conifers, it was found not to be phoretic on the southern pine beetle or six other associated beetles. This mite readily consumed brood of the southern pine beetle, but to be useful as a biological control agent.

\subsubsection{Pyemotes scolyti}

Pyemotes scolyti (Oudemans) using alternate hosts, has been suggested as a possible biological control agent for bark beetles (Beaver, 1967; Mills, 1983; Weiser, 1963).

\subsubsection{Hypoaspis sp. and Tetrapolypus rhynchophori}

The mite species, Hypoaspis sp. and Tetrapolypus rhynchophori Ewing (Pymotidae) have also been recorded infesting the adult 
beetles of Red palm weevil (Rhynchophorus ferrugineus) in coconut, India (Tamil-Nadu) (Peter, 1989).

\subsubsection{Predatory insects}

\subsubsection{Checkered beetles (Coleoptera: Cleridae)}

The checkered beetles or clerids prey both as adults and as larvae on the adults and brood of various bark beetle species. Adult clerids are attracted by pheromones emitted by bark beetles during the attack phase (Dahsten, 1982), and so (Aggregate on trees with abundant prey). Estimates range from less than $1 \%$ in the mountain pine beetle (Schmid, 1970) to $4 \%$ in the spruce beetle (Deyrup, 1975). Clerid larvae are general predators in the bark of infested trees, and are capable of mining through the bark to find their prey. Thanasimus formicarius (Linnaeus), a clerid from Germany released against the southern pine beetle in the eastern United States in 1882 and 1883 failed to get established (Hopkins, 1899; Dowden, 1962).

\subsubsection{Trogositid Beetles (Coleoptera: Trogositidae)}

Trogositids prey both as adults and as larvae on the adults and brood of various bark beetle species, as well as on other bark and wood-inhabiting insects. Adult trogositids are attracted by certain bark beetle pheromones and host tree volatiles (Bedard et al., 1969), enabling them to find high prey densities (numerical response by aggregation). Larval trogositids are voracious feeders capable of tunnelling through intact bark. Cannibalism tends to regulate their numbers in infested trees (Struble, 1942).

\subsubsection{Rhizophagid beetles (Coleoptera: Rhizophagidae)}

The genus Rhizophagus is holarctic, most often associated with various bark beetle species. Rhizophagus grandis (Gyllenhal) is the most studied rhizophagid in Europe; it is considered to be an important predator of Dendroctonus micans (Kugelmann) (Gohm et al., 1954; Karunakar et al., 1999). These predator releases were the only ones ever made in Canada against any bark beetle species.

\subsubsection{Long-legged flies (Diptera: Dolichopodidae)}

Many species of the genus Medetera has been reported as predators of bark beetles in North America, Europe and Asia (Kolomietz and Bogdanova, 1980; Dahsten, 1982; Mills, 1983). Adult flies of Medetera vary feed on small live insects on the surface of the bark of trees (De Leon, 1935). Fly larvae feed on eggs and larvae of bark beetle. All life stages of Medetera are preyed upon by other organisms. Larvae of Medetera sp., predacious on Dendroctonus micans in Russia, brought into the United States in 1978 for tests against Dendroctonus spp. died in quarantine (Coulson, 1981).

\subsubsection{Lonchaeid flies (Diptera: Lonchaeidae)}

Bedard in 1938 considered Lonchae corticis Taylor to be the most important predator of the Douglas-fir beetle, $D$. pseudotsugae, since he found $L$. corticis to be more abundant than Medetera, while Kline and Rudinsky (Kline and Rudinsky, 1964) consider L. corticis larvae to be more scavengers than predators in Douglas-fir beetle galleries. Lonchaea furnissi McAlpine, the most studied North American species, associated with the Douglasfir beetle, was found to be a scavenger (Johnsey et al., 1965). In the European and Asian literature various species of Lonchaea are considered to be predatory on bark beetle broods. Larvae of Lonchaea spp., predacious on Scolytidae (general), D. micans and on Blastophagus piniperda L. Scolytidae) in Russia, which were brought into the United States in 1978 and 1979 for tests against Dendroctonus spp. either were dead on arrival or died in quarantine (Coulsen, 1981).

\subsubsection{Robber flies (Diptera: Asilidae)}

Robber flies have on occasion been observed to capture and consume flying bark beetles (Mills, 1983) estimated a predation rate of $1 \%$ by Laphria gilm $\mathrm{L}$. on an emerging population of mountain pine beetles and suggested that numbers of this predator be supplemented.

\subsubsection{Snake flies (Neuroptera: Inocellidae and Raphidiidae)}

Snakefly larvae and adults have frequently been reported as predators or associates of bark beetles, their role in bark beetle ecology is poorly documented. Wichmann in 1957 considered snakefly larvae to be general predators on the bark surface of infested trees, and thought they may do more harm than good by consuming eggs of clerids and dolichopodids, the larvae of which are better predators of bark beetles.

\subsubsection{Flower bugs (Hemiptera: Anthocoridae)}

These bugs generally are quite small they can live within the bark beetle galleries. Both the nymphs and adults feed on all stages of bark beetles, using their piercing mouthparts to suck the juices from their prey. The abundance of anthocorids has been assessed only on trees attacked by southern pine beetle, where one species was found to be the most abundant predator (Lint and Stephen, 1983) (Table 1).

\subsubsection{Pirate bug (Hemiptera: Anthocoridae)}

The warehouse pirate bug, Xylocoris flavipes attacked most immature stages of beetles (Jay et al., 1968). The Red rust flour beetles were suppressed by warehouse pirate bugs in a warehouse (Press et al., 1975).

\subsubsection{Mammals}

It includes Insectivora, Rodentia, Chiroptera-shrews, rodents and bats. Miscellaneous small mammals consume bark beetles, particularly in overwintering sites at the bases of infested trees (Mills, 1983). Three types of insectivorous mammals (hedgehogs, moles and shrews) fed on Otio rhynchussulcatus. He stated that hedgehogs were prolific predators and on some occasions their diets were composed entirely of vine weevil adults. Moles were also recorded as predators of $O$. sulcatus (Breakey, 1959), but they tend to prefer moister areas than vine weevil. In the USA, Smith in 1932 observed predation by skunks and deer mice. 


\begin{tabular}{|c|c|c|c|c|}
\hline Predatory insect & Order & Family & Host & References \\
\hline \multirow{4}{*}{$\begin{array}{l}\text { Checkered Beetles, Thanasimus } \\
\text { formicarius }\end{array}$} & Coleoptera & Cleridae & Bark beetle, Dendroctonus sp. & (Dahsten, 1982) \\
\hline & & & Pine beetle & (Schmid, 1970) \\
\hline & & & $\begin{array}{l}\text { Spruce beetle, Dendroctonus } \\
\text { ruffipenis }\end{array}$ & (Dyer et al., 1975) \\
\hline & & & $\begin{array}{l}\text { Shot hole borer of tea, Xyleborus } \\
\text { fornicatus }\end{array}$ & (Austin, 1956) \\
\hline $\begin{array}{l}\text { Trogositid Beetles, Temnochila } \\
\text { chlorodia }\end{array}$ & Coleoptera & Trogositidae & Bark beetle, Dendroctonus sp. & (Berryman, 1967) \\
\hline $\begin{array}{l}\text { Rhizophagid beetles, } \\
\text { Rhizophagus grandis }\end{array}$ & Coleoptera & Rhizophagidae & $\begin{array}{l}\text { Great spruce bark beetle, } \\
\text { D. micans }\end{array}$ & $\begin{array}{l}\text { (Kobakhidze et al., } \\
\text { 1973) }\end{array}$ \\
\hline Paratheresia sp. & Diptera & Tachinidae & Larvae of red palm weevil & (Clausen, 1978) \\
\hline Robber fly & Diptera: & Asilidae & Bark beetle, Dandroctonus sp. & (Mills, 1983) \\
\hline $\begin{array}{l}\text { Lonchaeid Flies, Lonchaea } \\
\text { corticis }\end{array}$ & Diptera: & Lonchaeidae & $\begin{array}{l}\text { Spruce beetle, D. pseudotsugae, } \\
\text { D. micans and on Blastophagus } \\
\text { piniperda }\end{array}$ & $\begin{array}{l}\text { (Kline and Rudinsky, } \\
\text { 1964) }\end{array}$ \\
\hline Snakefly & Neuroptera & $\begin{array}{l}\text { Inocellidae and } \\
\text { Raphidiida }\end{array}$ & Bark beetle, Dandroctonus sp. & (Wichmann, 1967) \\
\hline Earwig, Chelisoches morio & Dermaptera & Forficulidae & $\begin{array}{l}\text { Red palm weevil, Rhynchophorus } \\
\text { ferrugineus eggs }\end{array}$ & $\begin{array}{l}\text { Abraham et al., } \\
1973\end{array}$ \\
\hline
\end{tabular}

\subsection{Parasitoids}

\subsubsection{Hymenoptera: Braconidae-Braconid wasps}

The family Braconidae contains the greatest number of genera reported to be parasitoids of bark beetles (Bushing, 1965). The genera Ropalophorus, Cosmophorusand Cryptoxilos contain species which are endoparasitoids of adult bark beetles (Bushing, 1965; Mills, 1983). The remaining genera are all ectoparasitoids of bark beetle larvae and occasionally of pupae.

\subsubsection{Dendrosoter protuberans and Ecphylus sileseacus (Braconidae)}

The family Braconidae contains the greatest number of genera reported to be parasitoids of bark beetles (Bushing, 1965). Two braconids, Dendrosoter protuberans (Nees) and Ecphylus sileseacus (Ratzeburg), have been brought into North America against the smaller European elm bark beetle, Scoiytus multistriatus (Marsham). D. protuberans was obtained from France in 1965 and released against S. multistriatus, starting in 1966 (Hosteler and Btewer, 1976; Schroder, 1974).

\subsubsection{Spathius benefactor (Braconidae)}

A native North American braconid, Spathius benefactor Matthews (S. canadensis Ashmead if reared from elm by Peacock in 1975 parasitizes the introduced elm bark beetle.

\subsubsection{Hymenoptera: Pteromalidae-Pteromalid Wasps}

The family Pteromalidae contains the second-greatest number of genera reported to be parasitoids of bark beetles Bushing, 1965. The genera Tomicobia and Karpinskiella are strictly endoparasitoids of adult bark beetles (Beda, 1965; Furniss and Carolin, 1977).

\subsubsection{Cheiropachus quadrum}

Supposedly of European origin, has been in North America at least since 1888 (Ashmead, 1988), yet adults of this species were imported into the United States in 1964 for release against S. multistriatus (Schroder, 1974).

\subsubsection{Rhopalicus tutela}

It is the only other pteromalid which has been imported and released against bark beetles.

\subsubsection{Parasitic wasp}

Parasitic wasps that attack stored grain beetles tend to be host specific, but there are several species that will attack more than one beetle species. e.g. Theocolax elegans will attack all of the stored grain weevils and the lesser grain borer.

\subsubsection{Anisopteromalus calandre and Lariophagus distinguendus}

This is true of the parasitic wasps and used against stored grain weevils.

\subsubsection{Cephalonomia waterstoni}

Cephalonomia waterstoni, which attacks the rusty grain beetle only attack a single species. These parasitoids are typically 
small ( 1 to $2 \mathrm{~mm}$ ), and do not feed on the grain. They will normally die within 5 to 10 days if no beetles are present in the grain. These parasitoids are found naturally in the grain, which suggests that after they are released they may continue to suppress pests for many years (Arbogast and Mullen, 1990). Because the adult wasps are external to the grain, they can be easily removed using normal grain-cleaning processes.

\subsubsection{Diptera: Phoridae-hump-backed flies}

The only non-hymenopterous parasitoid of bark beetles mentioned in the literature is the fly Megaselia aletiae
(Comstock) (Phoridae), which infests adults of the fir engraver, Scolytus wntralis LeConte. Parasitism apparently occurs during flight or attack, and parasitized females excavate normal galleries but lay no eggs. $1-2 \%$ of parent females were parasitized, a parasitism rate that was considered to be of minor importance (Ashraf and Berryman, 1969; Berryman, 1967) (Table 2).

4.3. Application of pathogenic microorganisms to prevent coleopteran pests

It includes the entomopathogenic bacteria, fungi, viruses and

Table 2: List of parasitoids used against different coleopteran pests

\begin{tabular}{llll}
\hline Parasitoid & Target pest & host & References \\
\hline $\begin{array}{l}\text { Lariophagus distinguendus (Larval } \\
\text { parasitoid) }\end{array}$ & $\begin{array}{l}\text { Rice weevil, Sitophilus oryzae, Maize weevil, } \\
\text { S. zeamais }\end{array}$ & Rice and maize & (Ryoo et al., 1991) \\
& Granary beetle, S. granarius & Stored grain pest & (Brower et al., \\
& & 1996) \\
$\begin{array}{l}\text { Scleroderma guani (Larval para- } \\
\text { sitoid) }\end{array}$ & Small and large longicorn species of beetles & Mulberry & (Press and Mullen, \\
$\begin{array}{ll}\text { Anisopteromalus calandrae } \\
\text { Cephalonomia waterstoni }\end{array}$ & Rice weevil, S. oryzae and Maize weevil, S. & Rice and Maize & 1992) \\
(Choo et al., 2001) & Rusty grain beetle, Cryprolestes ferrugieneus & Wheat & (Flinn et al., 1996) \\
\hline
\end{tabular}

nematodes.

\subsubsection{Entomopathogenic bacteria}

Despite the great bacterial diversity, those causing an infectious disease to insects bear a poor diversity if compared to other groups as protozoa and fungi. About 90 bacterial species cause infectious disease in insects, but only few of them have a great potential as biological control agents (Cloutier and Cloutier, 1992). Bacteria produce epizootics when there is high host density (stored product, insect colonies, fresh water populations subjected to particular physical or chemical conditions); in other circumstances epizootics are rare or are not detected (Castillo and Ponce, 1991).

\subsubsection{Bacillus thuriengiensis}

Bacillus thuriengiensis preparations make up the largest output of microbial pesticides in the world and are widely applied to control pests in agriculture, forestry, storage and medicine (Sun et al., 2003; Yu, 1990; Zhang and Deng, 1998). Eighty years ago, research was focused on finding strains toxic to Lepidoptera and Diptera pests. In 1983, Krieg and co-workers discovered the first $B$. thuriengiensis strain active against Coleopteran pests. Since then, new strains have been continuously discovered and much research on these strains has been carried out. One of the most harmful Coleopteran pests is Leptinotarsa decemlineata Say (Coleoptera: Chrysomelidae) which cause damage to potato and tomato crops in several regions of America and Europe. This insect has developed resistance against a variety of chemical pesticides.
There are also a number of Coleopteran pests that cause serious damages to forest and reserve materials, such as grain, food and forage. There is important to conduct research on $B$. thuriengiensis preparations to control Coleopteran pests.

\section{- Crystal protein against Coleopteran pests}

The current nomenclature distinguishes 174 holotype sequences that are grouped into 55 cry and 2 cyt families. A total of 47 toxins were tested against 39 species of Coleoptera in 190 bioassays. About $80 \%$ of bioassays pertained to four cry families: cry3 (32\%; $26.7 \%$ for cry3Aa alone), cry8 (24\%), cry1 (18.2\%; $9.1 \%$ for cry1B alone), and cry $34 / 35$ (8\%, alone or in combination). The broadest range of toxins was tested against Diabrotica sp. (23 toxins) and L. decemlineata (16 toxins). The only toxin was tested against a broad range of test species was Cry3Aa (23 species, from which $60 \%$ were susceptible) (Van Frankenhuyzen, 2009).

- Cry3A insecticidal crystal protein

$B$. thuriengiensis subsp. tenebrionis strain $\mathrm{BI} 256-82$ has a single insecticidal crystal protein gene, cry3A, which encodes a $73.1 \mathrm{kDa}$ protein. Under the effect of spore protease, the insecticidal crystal genes from Bacillus thuringiensis against coleopteran pest protein is degraded, forming a parasporal crystals, the crystals are solubilized in the midgut, resulting in active and toxic insecticidal peptides of 55 kDa (Krieg, 1983) (Table 3).

- Cry3B insecticidal crystal protein

B. thuriengiensis subsp. tolworthi, H9 strain EG2838 possess 
Table 3: Several important insecticidal crystal proteins against coleopterans were described [68] as follows: Insecticidal crystal genes from Bacillus thuringiensis against coleopteran pest

\begin{tabular}{|c|c|c|c|}
\hline cry gene & Bt strain & Target pest & References \\
\hline cry3Aa & Bt subsp. Tenebrionis strain B1256-82 & $\begin{array}{l}\text { L. decemlineata, C. scripta, Callosobruchus macu- } \\
\text { latus, Diabrotica balteata }\end{array}$ & (Sekar, 1987) \\
\hline cry3Bb & Bt EG4961 & L. decemlineata, Dandroctonus undecempunctata & $\begin{array}{l}\text { (Donavan et al., } \\
\text { 1992) }\end{array}$ \\
\hline cry3Ca & Bt kurstaki Btl109P & L. decemlineata & $\begin{array}{l}\text { (Lambert et al., } \\
\text { 1992) }\end{array}$ \\
\hline
\end{tabular}

the insecticidal crystal protein genes cry3B which encodes $74.2 \mathrm{kDa}$ proteins. A mixture of the spores and crystals of these strains have exhibited toxicity against $L$. decemlineata larvae. The spore crystal mixture of EG4961 has demonstrated specific toxic activity against Diabrotica undecempunctata howardi Barber (Coleoptera: Chrysomelidae) larvae (Dowden, 1962).

\section{- Cry3C insecticidal crystal protein}

The parasporal crystal of $B$. thuriengiensis subsp. gelleriae, strain BTS137J, is diamond-shaped, with a molecular weight of $129.4 \mathrm{kDa}$. The active fragment of $72 \mathrm{kDa}$ has shown toxic activity against $\mathrm{L}$. decemlineata.

- Cry3D insecticidal crystal protein

The cry3D protein of $B$. thuriengiensis subsp. kurstaki, $\mathrm{H} 3 \mathrm{ab}$ strain BT1109P, encoded by its corresponding gene, has higher toxicity against $L$. decemlineata than other cry3 proteins. Its $L_{50}$ value is $0.7 \mathrm{mg} \mathrm{ml}^{-1}$; this $L_{50}$ value was obtained by measuring the trypsin hydrolysate activity of cry3D by the leaf dipping bioassay (Lambert et al., 1992).

\section{- Application}

Several commercial bio-insecticides, such as M-one ${ }^{\mathrm{TM}}$, $\mathrm{M}$-trak ${ }^{\mathrm{TM}}$, Trident ${ }^{\mathrm{TM}}$ and Foil ${ }^{\mathrm{TM}}$, have been produced in the United States of America. These bio-insecticides, based on san diego and tenebrionsis subsp. are degined for the control of leaf-feeding flea beetle species including the Colorado potato beetle ( $L$. decemlineata), cottonwood leaf beetle ( $C$. scripta), Elm leaf beetle Pyrrhalta luteola Muller (Coleoptera: Chrysomelidae) and willow leaf beetle Plagiodera versicolora Laicharting (Coleoptera: Chrysomelidae) among others.

Among the $B$. thuriengiensis strains isolated in China, the C-001-006 and ES-017 strains exhibited different toxicity levels against Tenebrio molitor (Coleoptera: Tenebrionidae) and Anomala corpulenta larvae. A new strain of $B$. thuriengiensis, HBF-1, isolated from Hebei province, China has high insecticidal activity against $A$. exoleta (Coleoptera: Scarabaeidae) and A. corpulenta larvae and the mortality on first and second instars larvae of the cinnamon beetle treated with the strain was $100 \%$. This isolate is the first discovered and reported to have specific insecticidal activity against beetle larvae in China (Table 4).
Table 4: List Bacillus thuriengiensis based commercial products for the prevention of coleopteran pests

\begin{tabular}{lc}
\hline Company & Product \\
\hline Mycogen & M-one \\
Sandoz & Trident \\
Abbott & Ditera \\
Novo Biokontrol & Novodor \\
Ecogen & Foil \\
\hline
\end{tabular}

\subsubsection{Bacillus papillae}

It is an effective method of preventing Japanese beetle (Popilliae japonica) larvae; it was found a little later than B. thuriengiensis. In the 1930s, the strain was first isolated by Dutky from Japanese grubs that were infected by milky disease. B. popilliae is a pathogen of the golden tortoise beetle larvae. It is highly efficient and environmentally friendly States microbial insecticide promoted in the United States since 1939.

B. popilliae and the infected larvae can move in a large area before death increasing the infection probability of other beetle larvae. $B$. popilliae can maintain viability for several years the soil and drought conditions. The advantages of using commercial preparations of $B$. popilliae are its narrow host range (they are effective only against Japanese beetles) and their complete safety for humans and other vertebrates.

\subsubsection{Entomopathogenic fungi}

Among the biological control agents, the fungi play an important role for insect control. Many pathogenic fungi are natural control agents of many insect pests and other arthropods frequently cause epizooties and significantly reduce host populations. Although entomopathogenic fungi have long been recognized to exhibit a strong potential in controlling insect pests, attempts to manipulate fungi as real control agents began in the late ninetieth century with little or moderate success. There are more than 50 different fungal products registered, with nine able to control coleopterans (Yu, 2000).

In the last 20 years, many countries have carried out extensive research to examine the use of insect pathogenic fungi. Fungal insecticides mainly include Beauveria bassiana and Metarhizium anisopliae (Table 5). 


\begin{tabular}{|c|c|c|}
\hline \multicolumn{3}{|c|}{$\begin{array}{l}\text { Table 5: List of important fungal species against different } \\
\text { coleopteran pests }\end{array}$} \\
\hline Fungi & Target pest & References \\
\hline \multirow{10}{*}{$\begin{array}{l}\text { B. brong- } \\
\text { niartii } \\
\text { Metarhi- } \\
\text { zium aniso- } \\
\text { pliae }\end{array}$} & $\begin{array}{l}\text { Boll weevil, Anthonomus } \\
\text { grandis }\end{array}$ & (Wright, 1993) \\
\hline & $\begin{array}{l}\text { Rice water weevil, lis- } \\
\text { sorhoptrus oryzophilus }\end{array}$ & $\begin{array}{l}\text { (Rice and Cog- } \\
\text { bum, 1993) }\end{array}$ \\
\hline & $\begin{array}{l}\text { Red rust flour beetle, Tribo- } \\
\text { lium castanaeum }\end{array}$ & \\
\hline & $\begin{array}{l}\text { Citrus root weevil, Artipus } \\
\text { floridanus }\end{array}$ & $\begin{array}{l}\text { (Padin et al., } \\
\text { 2002) }\end{array}$ \\
\hline & $\begin{array}{l}\text { Lesser grain borer, Rhizop- } \\
\text { ertha domonica }\end{array}$ & (Lord, 2005) \\
\hline & Scarab beetle & $\begin{array}{l}\text { (Yokoyama, } \\
\text { 1998) }\end{array}$ \\
\hline & $\begin{array}{l}\text { Scarab beetle, Ectinohoplia } \\
\text { rufipes }\end{array}$ & $\begin{array}{l}\text { (Choo et al., } \\
\text { 2001) }\end{array}$ \\
\hline & $\begin{array}{l}\text { Rice weevil, Sitophilus ory- } \\
\text { zae Colorado potato beetle }\end{array}$ & (Batta, 2003) \\
\hline & $\begin{array}{l}\text { Scarab beetle, Ectinohoplia } \\
\text { rufipes }\end{array}$ & (Fujiie, 1993) \\
\hline & $\begin{array}{l}\text { Red Palm weevil, Rhyn- } \\
\text { chophorus ferrugineus }\end{array}$ & $\begin{array}{l}\text { (Prior and Ar- } \\
\text { uma, 1985) }\end{array}$ \\
\hline
\end{tabular}

\subsubsection{Beauveria bassiana}

The genus Beauveria has shown virulence against insects from order Coleoptera such as beetle larvae (Pu and Li, 1996). Beauveria belongs to the category of fungal agents, which is the most widely used category. After more than 20 years of extensive experiments and research, its target range has been greatly expanded. It has been used to kill borers, fruit tree pests and soil insects, among others (Gan et al., 2007). In the USA, attempts were made as early as 1962 by Nutrilite products to obtain registeration for $B$. bassiana as Biotrol $^{\mathrm{TM}}$, but these attempts were unsuccessful. A wettable formulation of $B$. bassiana conidia, based on isolate ARSEF 252, was developed by Abbott Laboratories and used in pilot tests against the Colorado potato beetle during the 1980s.

Results from field experiments using the Abbott's wettable formulation against the Colorado potato beetle were reported, although these results differed from year to year. Although the larval populations of the first and second generations adults were lower than that found for adults from the fenvalerate treatment group.

In the former Soviet Union, commercial preparations of $B$. bassiana (Boverin ${ }^{\mathrm{TM}}$ ) were applied to more than 10,000 ha of farmland, mainly against the Colorado potato beetle. In Belgium, under greenhouse conditions, an $84 \%$ control of introduced larvae of black vine weevil was obtained after an application of $2 \times 10^{8}$ conidia of $B$. brongniartii per liter of peat (Table 6).
Table 6: Fungal-based commercial products against Coleoptera

\begin{tabular}{|c|c|c|c|}
\hline Fungi & $\begin{array}{l}\text { Product } \\
\text { name }\end{array}$ & Target pests & $\begin{array}{l}\text { Manufactur- } \\
\text { er or country }\end{array}$ \\
\hline $\begin{array}{l}\text { Beauveria } \\
\text { bassiana }\end{array}$ & Boverin & $\begin{array}{l}\text { Leptinotarsa } \\
\text { decemlineata }\end{array}$ & $\begin{array}{l}\text { The former } \\
\text { Soviet Union }\end{array}$ \\
\hline B. bassiana & Boverol & L. decemlineata & $\begin{array}{l}\text { Czechoslo- } \\
\text { vakia }\end{array}$ \\
\hline B. bassiana & $\begin{array}{l}\text { Bovero- } \\
\text { sil }\end{array}$ & L. decemlineata & $\begin{array}{l}\text { Czechoslo- } \\
\text { vakia }\end{array}$ \\
\hline $\begin{array}{l}\text { Metarhizium } \\
\text { anisopliae }\end{array}$ & BioPat & $\begin{array}{l}\text { Coleopteran } \\
\text { pests }\end{array}$ & America \\
\hline M. anisopliae & Bioblas & $\begin{array}{l}\text { Coleopteran } \\
\text { pests }\end{array}$ & America \\
\hline M. anisopliae & Biogreen & $\begin{array}{l}\text { Coleopteran } \\
\text { pests }\end{array}$ & Australia \\
\hline
\end{tabular}

\subsubsection{Metarhizium spp.}

The most common control agent is Metarhizium anisopliae var. anisopliae Sorokin. The soil-inhabitating larvae of scarab beetles are typically hosts of Metarhizium spp. and coevolution has led to some isolates being specific to one or two genera of scarab.

\section{- Application}

In Australia, Biogreen ${ }^{\mathrm{TM}}$ and BioCane $\mathrm{B}^{\mathrm{TM}}$ are the two registered myco-insecticides for coleoptera pests. Biogreen ${ }^{\mathrm{TM}}$ is a granular product consisting broken rice particles on which spores of M. flavoviridae grow. It has been used to control red-headed pasture cockchafer, Adoryphorus couloni (Coleoptera: Scarabaeidae), in turf and pasture in Victoria and Tasmania. Another rice granule formulation of $M$. anisopliae var. anisopliae isolate $\mathrm{FI}-1045$ is highly virulent against the greyback canegrub, Dermolepida albohirtum (Coleoptera: Scarabaeidae), which is the worst single pest in Australia, causing losses over $\$ 5 \mathrm{M}$ per year. Extensive field trials over several seasons have shown that BioCane ${ }^{\mathrm{TM}}$ applied correctly at $33 \mathrm{~kg} \mathrm{ha}^{-1}$ or $6.6 \times 10^{13}$ conidia ha-1 leads to $50 \%$ to $60 \%$ control of that season's grubs.

In America, BioPat ${ }^{\mathrm{TM}}$ and Bioblast ${ }^{\mathrm{TM}}$ are two myco-insecticides registered for the control of Coleoptera. In China, spray spore suspensions of $M$. anisopliae control nearly $50 \%$ of rice water weevil population 7-9 days after application. When M. anisopliae was used to control the North China black Melolonthidae larvae by the Shanxi Institute of Zoology, larval mortality was increased as spore concentration increased. At spore concentrations of $2.1 \times 10^{4}, 1.9 \times 10^{5}, 2.2 \times 10^{7}, 2.0 \times 10^{7}$ and $1.8 \times 10^{8} \mathrm{cfu} / \mathrm{ml}$, the mortality of larvae was $20 \%, 65 \%, 90 \%$, $100 \%$ and $100 \%$, respectively.

\subsubsection{Microsporidia}

First considered to be early diverging intracellular parasites 
and most often grouped with the Protozoa, microsporidia now are considered to be fungi. Microsporidia, pathogenic protists related to the Fungi, are considered to be primary pathogens of many aquatic and terrestrial insect species and have important roles in insect population dynamics, managed insect disease, and biological control of insect pests.

Hosts are infected when spores are ingested and/or by transmission via the eggs. When ingested, spores germinate in a unique fashion: a polar tube that is coiled within the spore rapidly everts and punctures the host midgut cells, injecting the spore contents into the cell cytoplasm. Effects on the host are typically chronic; therefore, the use of microsporidia in biological control programs focuses on inoculative introductions, augmentative release, and conservation biology.

\subsubsection{Nosema scripta (Microsporida:Nosematidae)}

It is a species of microsporidian parasite, is described from the cottonwood leaf beetle, Chrysomela scripta (Coleoptera: Chrysomelidae), in North America (Bauer, 1993). Bothhorizontal transmission and vertical transmission have been demonstrated for this microsporidium in C. scripta in the laboratory. The Colorado potato beetle, Leptinotarsa decemlineata (Say), was susceptible to infection with this pathogen in cross-infectivity studies.

\subsubsection{N. epilachnae and N. varivestis}

$N$.epilachnae and $N$. varivestis are the North American species used as biological control

Against Mexican bean beetle, Epilachna varivestis (Coleoptera: Coccinellidae) (Brooks et al., 1985) (Table 7).

Table 7: List of microsporidia used against different coleopteran pests

\begin{tabular}{lll}
\hline $\begin{array}{l}\text { Microspo- } \\
\text { ridia }\end{array}$ & Host & References \\
\hline $\begin{array}{l}\text { Nosema } \\
\text { whitei }\end{array}$ & $\begin{array}{l}\text { Red rust flour beetle, Tribo- } \\
\text { N. scripta castanaeum }\end{array}$ & $\begin{array}{l}\text { (Khan and Sel- } \\
\text { man, 1988) }\end{array}$ \\
& $\begin{array}{l}\text { Cotton wood leaf beetle, } \\
\text { notarsa decemlineata, bean }\end{array}$ & (Bauer, 1993) \\
& $\begin{array}{l}\text { leaf beetle, Ceratoma trifur- } \\
\text { cata }\end{array}$ & \\
$\begin{array}{l}\text { N. epilach- } \\
\text { nae and N. } \\
\text { varivestis }\end{array}$ & lachna varivestis & (Brooks, 1995) \\
\hline
\end{tabular}

\subsubsection{Entomopathogenic nematodes}

These nematodes search for their host insects based on the chemical stimulation of the host itself or of other substances. The smell of the excrement of the host or the carbon dioxide generated by its respiration may lure the nematodes in the infection period (Gaugler, 1981) (Table 8).
Entomopathogenic nematodes in the family's Steinernematidae and Heterorhabtidae of the order Rhabtida are effective control agents of dozens of insect species in soil and cryptic habitats (Georgis and Gaugler, 1991; Kaya and Gauler, 1993; Koppenhofer et al., 2000). In India two recorded nematode species are Praecocilenchus ferruginophorus and $P$.

\begin{tabular}{|c|c|c|}
\hline \multicolumn{3}{|c|}{ Table 8: List of nematodes } \\
\hline $\begin{array}{l}\text { Nematode spe- } \\
\text { cies }\end{array}$ & Host & References \\
\hline $\begin{array}{l}\text { Steinernema } \\
\text { scarabaei }\end{array}$ & $\begin{array}{l}\text { White grubs, } \\
\text { Exomala orientalis }\end{array}$ & $\begin{array}{l}\text { (Stock and Kop- } \\
\text { penhofer, 2003) }\end{array}$ \\
\hline $\begin{array}{l}\text { Heterorhabditis } \\
\text { bacteriophora }\end{array}$ & $\begin{array}{l}\text { White grubs, Orien- } \\
\text { tal beetle, Exomala } \\
\text { orientalis }\end{array}$ & $\begin{array}{l}\text { (Koppenhofer } \\
\text { and Fuzy, 2003) }\end{array}$ \\
\hline \multirow[t]{2}{*}{$\begin{array}{l}\text { Steinernema } \\
\text { kushidai }\end{array}$} & $\begin{array}{l}\text { June beetle, Poly- } \\
\text { phylla decemlineata }\end{array}$ & (Mamiya, 1989) \\
\hline & Popillia japonica & $\begin{array}{l}\text { (Artyukhovsky, } \\
\text { 1967) }\end{array}$ \\
\hline
\end{tabular}

rhaphidiophorus used against red palm weevil (Rhynchophorus ferrugineus) in coconut. $P$. ferruginophorus was recovered from R. ferrugineus in India (Rao and Reddy, 1980).

Sugarcane white grub, Holotrichia serrata was found susceptible to EPNs (Karunaker et al., 1999; Shankamarayan et al., 2006). It was biologically controlled by Heterorhabditis indica isolate from India and other countries (Stack et al., 2000). Research on biological control of white grubs in sugarcane using indigenous EPNs strain was carried out at $\mathrm{SBI}$, Coimbatore under an international collaborative research project involving leading research laboratories from Ireland and Germany.

\section{- Application}

In China, a parasitic nematode was used to control Actinidia chinensis, which parasitizes Ephedra equisetina. The larval mortality reached $94.4 \%$ to $100 \%$ in $4-6$ days after application. In the forest, each warm hole contained 10,000 infective nematodes, leading to greater than $90 \%$ control. Steinernema was used to control Anomala germari, which occurs on the poplar. Each hole was injected with 6,000 Steinernema and the mortality was about $82.1 \%$ (Liu, 1993). Banana plants were treated with a S. carpocapsae oreparation to control the black weevil, and the larval mortality was between $73 \%$ and $90 \%$, the mortality of pupa was between $68 \%$ and $92 \%$, and the mortality of adult was between 25 and $80 \%$.

Entomopathogenic nematodes are a new biological control factor with greater variation. More than 2,000 strains have been reported and experts dedicated to the transgenesis and molecular biology of namatodes hope to produce heatresistant, anti-drought nematode strains in order to expand their production and application. Therefore, these will play a greater role in bio-ecological agricultural pest control systems. 


\subsubsection{Viruses}

Viruses are considered excellent candidates for insect pest control, mostly because they are highly specific, as they show no negative effect on plant, domestic animal, birds, fish or non-target insect. Viruses, as many of their infections cause lethal diseases to susceptible individual and therefore they can be important biotic factors to keep insect pest population densities under control.

\subsubsection{Oryctes virus}

In 1966, Huger placed the Oryctes virus in a new genus and named it Rhabdionvirus orycte ones like Baculovirus oryctes under Nudibaculovirinae. However, this pathogen has recently been removed from the Baculoviridae and placed under its own virus category-Oryctes (Evans and Shapiro, 1997). Further studies on the virus structure strengthened its inclusion under Baculoviridae and it was named Baculovirus oryctes (David, 1975; Payne, 1974).

The coconut is an important plantation crop in India. The rhinoceros beetle, Oryctes rhinoceros L. (Coleoptera: Scarabaeidae) is a serious pest of coconut throughout India and Southeast Asia, causing an estimated $10 \%$ yield loss in the crop. Successful biological control of this pest could be achieved using the non-occluded Oryctes virus (syn. Baculovirus oryctes or Oryctes baculovirus) (Evans and Shapiro, 1997).

Oryctes virus also used as biological control against the other species of rhinoceros beetle like Oryctes nasicornis (Huger, 1966), O. boa (Julia and Mariau, 1976), O. monoceros (Purrini, 1989), Taro beetle, Papuana uninodis (Zelazny et al., 1998), Brown rhinoceros beetle Xylotrupes Gideon (Danger et al., 1994), Mango seed weevil, Sternochetus mangiferae (Shukla et al., 1984). Cashew stem and root Borer, Ploceaderus obesus and $P$. ferrugieneus.

\subsubsection{Cytoplasmic polyhedrosis virus}

There is one record in the literature of viruses being recovered from palm weevils. In 1990 Gopinadhan and co-workers found a highly potent cytoplasmic polyhedrosis virus (CPV) specific to red palm weevil in Kerala, India. The virus infected all stages of the insect and laboratory infection of the late larval stages resulted in the development of malformed adults.

\subsubsection{Application of entomopathogenic virus}

A practical method of virus dissemination is through the release of virus-infected adults (Bedford, 1981). An inoculum is prepared by homogenizing $1 \mathrm{~g}$ infected larval tissue in 1 litre of phosphate buffer (0.05 M, pH 8.0) and 3\%sucrose, which amounts to 31.6 LD $_{50}$ dose (Mohan et al., 1989). Healthy beetles collected from the field are allowed to wade through virus inoculums contained in a basin for $30 \mathrm{~min}$. The beetles can also be inoculated with the sterile viral filtrate prepared as described by Zelazny and co workers in 1987.

After this swim treatment beetles are confined together for 12 to $24 \mathrm{hrs}$, and released after dusk at the rate of 15 inoculated beetles per hectare (Mohan et al., 1989). This method eliminates the disadvantages of other methods of application, where a compost heap or a split coconut log heap is prepared artificially and inoculated with virus killed larval tissues (Bedford, 1981).The infected beetles disperse widely before death, spreading the disease directly into the wild population, and contaminating breeding sites which may contain larval broods and other beetles, including the palm crowns (Zelazny, 1976).

\section{Conclusion}

Researches and applications of biological control of coleopteran pests have made a great progress in recent decades. Major commercial products are based on Bacillus thuringiensis, Paenibacillus popilliae, Metarhizium anisopliae and Baeuveria bassiana. Entomopathogenic nematodes show good efficacy toward the soil inhabitating insect pests. Parasitoids and predators will be useful elements of a strategic approach to control the coleopteran pests. Overall, there is good evidence that accelerated exploration of biological control options may provide the advances in coleopteran pest management.

\section{References}

Abraham, V.A., Kurian, C., Nayer, N.M., 1973. ChelisochesmorioF. (Forficulidae: Dermaptera), a predator on eggs and early instar grubs of the red palm weevil Rhynchophorus ferrugineus F. (Curculionidae:Coleoptera). Journal of Plantation Crops 1, 147-152.

Arbogast, R.T., Mullen, M.A., 1990. Interaction of maize weevil (Coleoptera: Curculionidae) and parasitoid Anisopteromalus calandrae (Hymenoptera:Pteromalidae) in a small bulk of stored corn. Journal of Economic Entomology 83, 2462-2468.

Artyukhovsky, A.K., 1967. Neoaplectana arenaria nov. sp. (Steinernematidae, Nematoda) inducing nematode disease in chafers of the Voronezh region. Trudy Voroneszhskogo Gosudarstvennogo Zapovednika 15, 94-100.

Ashmead, W. H., 1988. On the Chalcideous tribe Chiropachides. Canadian Entomology 20(9), 172-176.

Ashraf, M., Berryman, A.A., 1969. Biology of Scolytus wntralis (Coleoptera: Scolytidae) attacking Abies grandisin northern Idaho. Melanderia 2, 1-23.

Austin, G.D., 1956. Historical review of shot-hole borer investigations. The Tea Quarterly 27(4), 97-102.

Baldwin, P.H., 1968. Predator-prey relationships of birds and spruce beetles. Proc. North Central Br. Entomological Society of America 23(2), 90-99.

Batta, Y.A., 2003. Production and testing of novel formulations of the entomopathogenic fungus Metarhizium anisopliae (Metch.) Sorokin (Deuteromycotina: Hyphomycetes). Crop Protection 22(2), 415-422. 
Bauer, L.S., 1993. The response of the cottonwood leaf beetle, Chrysomela scripta, to Bacillus thuringiensis var. san diego. Environmental Entomology 18, 261-267.

Beaver, R.A., 1967. Notes on the biology of the parasitic mite Pyemotes scolyti Oud. (Acari: Pyemotidae). The Entomologist 100(1244), 9-12.

Bedard, W.D., 1938. An annotated list of the insect fauna of Douglas fir (Pseudotsuga mucronata Rafinesque) in the northern Rocky Mountain region. Canadian Entomology 70, 188-197.

Bedard, W.D., 1965. The biology of Tomicobia tibialis (Hymenoptera: Pteromalidae) parasitizing Ips conlusus (Coleoptera: Scolytidae) in California. Contrib. Boyce Thompson Institute 23(4), 77-81.

Bedard, W.D., Tilden, P.E., Wood, D.L., Silverstein, R.M., Brownlee, R.G., Rodin, J.O., 1969. Western pine beetle: field response to its sex pheromone and a synergistic host terpene, myrcene. Science 164, 1284-1285.

Bedford, G.O., 1981. Control of the rhinoceros beetle by baculovirus, 409-426. In Microbial Control of Pests and Plant Diseases, 1970-1980. Burges, H.D. (Edn.), Academic Press, London.

Berryman, A.A., 1973. Population dynamics of the fir engraver, Scolytus wntralis (Coleoptera:Scolytidae). Analysis of population behavior and survival from 1964 to 1971. Canadian Entomology 105(11), 1465-1488.

Blackman, M.W., 1931. The Black Hills beetle (Dendroctonus ponderosae Hopk.). Bull. N.Y. State College of Forestry, 4(4), Technical Publication No. 36, 97.

Bollinger, E.K., Caslick, J.W., 1985. Red-winged Blackbird (Agelaius phoenicus) predation on Northern corn rootworm beetles (Diabrotica longicornis) in field of corn (Zea mays). Journal of Applied Ecology 22, 39-48.

Brooks, W.M., Hazard, E.I., Becnel, J., 1985. Two new species of Nosema (Microsporida:Nosematidae) from the Mexican bean beetle Epilachna varivestis (Coleoptera: Coccinellidae). Journal of Protozoology 32, 525-535.

Breakey, E.P., 1959. Control of root weevils in strawberry plantings. Journal of Economic Entomology 52, 11171119.

Berryman, A.A., 1967. Preservation and augmentation of insect predators of the western pine beetle. Journal of Forestry 65, 260-262.

Brower, J.H., Smith, L., Vail, P.V., Flinn, P.W., 1996. Biological Control, pp 223-286. In: Subramanyam, B., Hagstrum, D.W. (eds.) 1996; Integrated management of insects in stored products. Marcel Dekker, N.Y., Bull, E.L., Meslow, E.C., Habitat requirements of the pileated woodpecker in northeastern Oregon. Journal of Forestry 75(6), 335-337.

Bushing, R.W., 1965. A synoptic list of the parasites of Scolytidae (Coleoptera) in North America North of Mexico. Canadian Entomology 97(5), 449-492.

Castenieras, A.T., Ponce, E., 1991. Efectividad de la utilizacion de Pheidole megacephala (Hymenoptera: Formicidae) en la lucha biologica contra Cosmopolites sordidus (Coleoptera:Curculionidae). Proteccion de Plantas 1, 15-21.

Castillo, P., Acosta, N., Ciliezar, A., 1995. Control microbiologica de plagas arthropodas. In: EAP (Ed.), Manual para la ensenanza del control biologica en America Latina. Zamorano, Honduras 51-72.

Choo, H.Y., Lee, D.W., Park, J.W., Lee, J.W., 2001. Comparison of four major scarab beetles, Ectinohoplia rufipes, Adoretus tenuimaculatus, Exomala orientalis and Popilliaquadriguttata in golfcourses. Korean Turfgrass Sciences 13, 101-112.

Clausen, C.P., 1978. Introduced parasites and predators of arthropod pests and weeds: a word review. US Deptartment of Agriculture. Handbook 480, 545.

Cline, L.D., Press, J.W., Flaherty, B.R., 1985. Suppression of the rice weevil, Sitophilus oryzae (Coleoptera, Curculionidae) inside and outside of burlap, woven polypropylene, and cotton bags by the parasitic wasp. Anisopteromalus calandrae (Hymenoptera: Pteromalidae). Journal of Economic Entomology 78, 835-838.

Coulson, J.R., 1981. The Soviet-American Environmental Agreement and exchange of beneficial or $g$ a $n$ i s $\mathrm{m} \mathrm{s}$, 1972-1979. in: Coulson, J.R. (ed.). Proc. Joint AmericanSoliet Conference on Use of Beneficial Organisms in the Control of Crop Pests. Washington, D.C., Aug. 13-14, 1979; The Entomological Society of America 1-11.

Cloutier, C.,Cloutier, C., 1992. Les solutions biologiques de Lutte pour la repression des insects $T$ acariens ravageurs des cultures. In : Vincent, C., Coderre, D. (Eds.), La Lutte Biologique. Tec \& Doc Lavoisier, Quebec, Canada, 33.

Dahlsten, D.L., 1982. Relationships between bark beetles and their natural enemies. Chapter 5 in: Mitton, J.B., Sturgeon, K.B. (eds.). Bark beetles in North American Conifers-A System for the Study of Ewlutionary Biology. University of Texas Press, Austin, 527, 140-182.

Dangar, T.K., Solomon, J.J.,Pillai, G.B., 1994. Infection of the coconut palm beetle, Xylotrupes Gideon (Coleoptera:Scarabaeidae) by a nonoccluded baculovirus. Z. Pflankranh. Pflschutz. 101(6), 561-566.

David, W.A.L., 1975. The status of viruses pathogenic for insects and mites. Annual Review of Entomology 20, 97-117.

De Leon, D.A., 1935. The study of Medetera aldrichii Who (Diptera-Dolichopodidae), a predator of the mountain pine beetle (Dendroctonus monticolae Hopk., Coleoptera-Scolytidae). Entomological Society of America 15(2), 59-89.

Deyrup, M.A., 1975. The insect community of dead and dying Douglas-fir: I. The Hymenoptera. Coniferous Forest Biome Ecosystem Analysis Studies, IBP, Bull. No.6, 104. Donovan, W.P., Rupar, M.J., Slanley, A.C., Malvar, T., GawronBurke, M.C., Johnson, T.B., 1992. Characterization of two 
genes coding Bacillus thuringiensis insecticidal crystal proteins toxic to Coleopteran species. Applied and Environmental Microbiology 58, 3921-3927.

Dowden, P.B., 1962. Parasites and predators of forest insects liberated in the United States through 1960. USDA For. Servo Agric. Handbook No. 226, 70.

Dyer, E.D.A., Hall, P.M., Safranyik, L., 1975. Numbers of Dendroctonus rujipennis (Kirby) and Thanasimus undatulus Say at pheromone-baited poisoned and unpoisoned trees. Journal of Entomological Society of Biological Control 72, 20-22.

Evans, K.E., Conner, R.N., Snag management. in: De Graaf, R.M., Evans, K.E. (Eds.). Management of North Central and Northeastern Forests for Nongame Birds. Workshop Proc., Jan. 23-25, 1979, Minneapolis, Minnesota. USDA For. Serv., North Central Forest Experiment Station, General Technical Report, NC-51, 214-225.

Evans, H., Shapiro, M., 1997. Viruses, pp. 17-52. In Manual of Techniques in Insect Pathology (Edited by L.A. Lacey), Academic Press, San Diego, California.

Flinn, P.W., Hagstrum, D.W., McGaughey, W.H., 1996. Suppression of beetles in stored wheat by augmentative releases of parasitic wasps. Environmental Entomological 25, 505-511.

Fujiie, A., Yokohama, T., Fujikata, M., Sawada, M., Hasegawa, M., 1993. Pathogenicity of an entomogenous nematode, Steinernema kushidai Mamiya (Nematoda: Steinernematidae), on Anomala cuprea (Coleoptera: Scarabaeidae). Japanese Journal of Applied Entomology and Zoology 37, 53-60.

Furniss, R.L., Carolin, V.M., 1977. Western Forest Insects. U.S.D.A. For. Servo Misc. Publication No. 1339, 654.

Gan,Y.Y., Qiang, J.H., Jia, S.H., 2007. Technology on preventing Monochamous alternates larvae with Beauveria bassiana. China Forestry Science and Technology 21(1), 69-71.

Gaugler, R., 1981. Biological control potential of neoaplectanid nematodes. Journal of Nematology 13, 241-249.

Georgis, R., Gaugler, R., 1991. Predictability in biological control using entomopathogenic nematodes. Journal of Economic Entomology 84, 713-720.

Gohrn, V., Henriksen, H.A., Petersen, B.B., 1954. Observations of Hylesinus (Dendroctonus) micans Kug. Life history. Investigations on two attacks in sitka spruce. Control Experiments. (Dan., eng. summ.). Saertryk af Det forstlige Forsogsvaesen I Danmark 21(4), 383-433.

Gopinadhan, P.B., Mohandas, N., Nair, K.P.V., 1990. Cytoplasmic polyhedrosis virus infecting Red palm weevil of coconut. Current Science 59, 577-580.

Hopkins, A.D., 1899. Report on investigations to determine the cause of unhealthy conditions of the spruce and pine from 1880-1893. West Virginia Agricultural Experiment Station, Bulletin 56, 197-461.
Hostetler, B.B., Brewer, J.W., 1976. Survival of Dendrosoter protuberans, a parasitoid of Scolytus multistriatus, in Colorado. Annals of Entomological Society of Entomology 69(1), 85-88.

Huger, A.M., 1966. A virus disease of the Indian rhinoceros beetle, Oryctes rhinoceros (Linnaeus), caused by a new type of insect virus, Rhabdionvirus oryctes. Invertibrate Pathology 8, 38-51.

Jay, E., Davis, R., Brown, S., 1968. Studies on the predacious habits of Xylocoris flavipes (Reuter) (Hemiptera: Anthocoridae). Journal of Georgia Entomological Society 3, 126-130.

Johnsey, R.L., Nagel, W.P.,Rudinsky, J.A., 1965. The Diptera Medetera aldrichii Wheeler (Dolichopodidae) and Lonchaea furnissi McAlpine (Lonchaeidae) associated with the Douglas-fir beetle in western Oregon and Washington. Canadian Entomology 97(5), 521-527.

Julia, J.F., Mariau, D., 1976. Research on Oryctes monoceros. In Ivory Costa II. Trial of biologicalcontrol by virus Rhabdionvirus oryctes. Oleagineux 31, 113-117.

Karunakar, G., Easwaramoorthy, S., David, H., 1999. Suscptibility of nine lepidopteran insects to Steinernemaglaseri, S. feltiae and Heterorhabditis indicus infection. International Journal of Nematology 9, 68-71.

Kaya, H.K., Gaugler, R., 1993. Entomopathogenic nematodes. Annual Review of Entomology 38, 181-206.

Khan, A.R., Selman, B.J., 1988. On the mortality of Tribolium castaneum adults treated sublethally as larvaewith pirimiphos-methyl, Nosema whiteiand pirimiphos-methyl+Nosema whitei doses. Enromophaga 33, 377-380.

Kinn, D.N., 1971. The life cycle and behavior of Cercoleipus coelonotus (Acarina: Mesostigmata), includinga survey of phoretic mite associates of California.Scolytidae. University of California Publcation in Entomology 65-66.

Kline, L.N., Rudinsky, J.A., 1964. Predators and parasites of the Douglas-fir beetle: description and identification of the immature stages. Oregon Agricultural Experiment Station and Technology. Bulletin 79, 52.

Kobakhidze, D.N., Kharazishvili, K.V., Tvaradze, M.S., Kraveyshvili, I.K., 1973. On the natural enemies of the European spruce beetle Dendroctonusmicans Kugel. (Coleoptera, Scolytidae), in Georgia. Annual Review of Enomology 52(1), 30-32.

Kolomietz, N.G., Bogdanova, D.A., 1980.Parasites and Predators of Xylophagous Insects of Siberia.

(Russ.). Siberian Branch of the USSRAcademy of Science, Sukachev Institute of Forestand Wood, Novosibirsk, 277.

Koppenhofer, A.M., Grewal, P., Kaya, H.K., 2000. Synergism of imidacloprid and entomopathogenic nematodes against white grubs: the mechanism.Entomologia Experimentalis et Applicata 94, 283-293.

Koppenhofer, A.M., Fuzy, E.M., 2003. Ecological characterization of Steinernema scarabaei, a scarab- 
adapted entomopathogenic nematode from New Jersey. Journal Invertebrate Pathology. 2003 (in press).

Koplin, J.R., 1972. Measuring predator impact of woodpeckers on spruce beetles. The Journal of Wildlife Management 36, 308-320.

Krieg,A., Huger, A.M., Langenbruch, G.A., Schnetter, W., 1983.Bacillus thuringiensis Var. tenebrionis: ein neuer, gegenuber Larven von Coleopteran wirksamer Pathotyp. Zeitschrift fir Angewendte Entomologie1983, 96, 500-508.

Lambert, B., Hofte, H., Annys, K., Jansenes, S., Soetaert, P., Pefereon, M., 1992. Novel Bacillus thuringiensis insecticidal crystal protein with a silent activity against coleopteran larvae. Applied and Environmental Microbiology 58(8), 2536-2542.

Linit, M.J., Stephen, F.M., 1983. Parasite and predator component of within-tree southern pine beetle (Coleoptera: Scolytidae) mortality. Canadian Entomology 115(6), 679-688.

Lindquist, E.E., 1969. Review of holarctic tarsonemid mites (Acarina: Prostigmata) parasitizing eggs of pine bark beetles. Canadian Entomological Society 60, 1-111.

Liu, N.X., 1993. Entomopathogenic nematodes in Chinese fields and experimental research. Insect Natural Enemies 15(2), 96-100.

Lord, J.C., 2005. Low humidity, moderate temperature, and desiccant dust favor efficacy of Beauveria bassiana (Hyphomycetes: Moniliales) for the lesser grain borer, Rhyzopertha dominica (Coleoptera: Bruchidae). Biological Control 34, 180-186.

Mamiya Y., 1989.Comparison of the infectivity of Steinernema kushidai (Nematoda: Steinernematidae) andother steinernematid and heterorhabditid nematode for three different insects. Applied Entomology and Zoology24, 302-308.

Mills, N.J., 1983. The natural enemies of scolytids infesting conifer bark in Europe in relation to the biological control of Dendroctonus spp. in Canada. Biocontrol News and Information4(4), 305-328.

Mohan, K.S., Jayapal, S.P., Pillai, G.B., 1989. Biological suppression of coconut rhinoceros beetle Oryctes rhinoceros (L) in Minicoy, Lakshadweep by Oryctes baculovirus: Impact on pest population and damage of Plantation Crops 16, 163-170

Moser, J.C., 1975. Mite predators of the southern pine beetle. Annals of the Entomological Society of America 68(6), 1113-1116.

Moser, J.C., Kietczewski, B., Wisniewski, J., Batazy, S., 1978. Evaluating Pyemotes dryas (Vitzthum1923) (Acari: Pyemotidae) as a parasite of the southern pine beetle. International Journal of Acarology 4(2), 67-70.

Moser, J.C., 1981. Transfer of a pyemotes egg parasite phoretic on western pine bark beetles to the southern pine beetle. International Journal of Acarology 7(1-4),
197-202.

Moser, J.C., Cross, E.A., Roton, L.M., 1971. Biology of Pyemotes parriscolyti (Acarina: Pyemotidae). Entomophaga 16, 367-379.

Otvos, I.S., 1969.Vertebrate predators of Dendroctonus brevicomis LeConte (Coleoptera: Scolytidae), withspecial reference to Aves. PhD Thesis, Univ. ofCalifornia, Berkeley, 202.

Otvos, I.S., 1979. The effects of insectivorous bird activities in forest ecosystems: an evaluation. in: Dickson, J.G. et al. (eds.). The Role of Insectivorous Birds in Forest Ecosystems. Academic Press, N.Y., 381, 341-374.

Padin, S., Dal-Bello, G., Fabrizio, M., 2002. Grain loss caused by Tribolium castaneum, Sitophilus oryzae, and Acanthoscelides obtecus in stored durum wheat and beans treated with Beauveria bassiana. Journal of Stored Products Research 38(1), 69-74.

Paulson, G.S., Akre, R.D., 1992. Evaluating the effectiveness of ants as biological control agents of pear psylla. Journal of Economic Entomology85, 70-73.

Payne, C.C., 1974. The isolation and characterization of a virus from Oryctes rhinoceros. Journal of General Virology 25, 105

Peacock, J.W., 1975. Research on chemical and biological control of elm bark beetles. in; D.A. Burdekinand H.M. Heybroek (compilers). Dutch Elm Disease. Proc. IUFRO Conf., Minneapolis - St.Paul, USA, Sept. 1973. USDA For. Serv., Northeastern For Experimental Station. , PA., 94, 18-52.

Peter, C., 1989. A note on the mites associated with the red palm weevil, Rhynchophorus ferrugineus Oliv. in Tamil Nadu. Journal of Insect Science 2, 160-161.

Press, J.W., Flaherty, B.R., Arbogast, R.T., 1075. Control of the red flour beetle, Tribolium castaneum, in a warehouse by a predaceous bug, Xylocoris flavipes. Journal of Georgia Entomological Society 10, 7678.

Press, J.P., Mullen, M.A., 1992. Potential of the weevil parasitoid, Anisopteromalus calandrae (Howard) (Hymenoptera: Pteromalidae) for protecting commercially packaged wheat from infestation by the rice weevil, Sitophilus oryzae (L.) (Coleoptera: Curculionidae). Journal of the Kansas Entomological Society 65, 348-351.

Prior, C., Arura, M., 1985. The infectivity of Metarhizium anisopliae to two insect pests of coconuts. Journal of Invertebrate Pathology 45, 187-194.

Pu, Z.L., Li, Z.Z., 1996. Insect Mycology. Anhui Science and Technology Press, Hefei, China. 88. Purrini, K., 1989.Bacidovirus oryctes release into Oryctes monocerospopulation in Tanzania with special reference to interaction of virus isolates used in ourlaboratory infection experiments. Journal of Invertibrate Pathology 53, 285-300.

Rao, P.N., Reddy, Y.N., 1980. Description of a new nematode Praecocilienchus ferruginophorus $\mathrm{n}$. $\mathrm{sp}$. from weevil 
pests (Coleoptera) of coconut palms in South India. Rivista di Parassitologia 44, 93-98.

Rice, W.C., Cogburn, R.R., 1993. Activity of entomopathogenic fungus Beauveria bassiana (Deuteromycota: Hyphomycetes) against three coleopteran pests of stored grain. Journal of Economic Entomology 92, 691-694.

Risch, S., 1981. Ants as important predators of rootworm eggs in Neotropics. Journal of Economic Entomology 74, 88-90.

Ryoo, M.I., Hong, Y.S., Yoo, C.K., 1991. Relationship between temperature and development of Lariophagus distinguendus (Hymenoptera: Pteromalidae), an ectoparasitoid of Sitophilus oryzae (Coleoptera: Curculionidae). Journal of Economic Entomology 84, 825-829.

Stock, S.P., Koppenhofer, A.M., 2003. Steinernema scarabaei n. sp. (Rhabditida: Steinernematidae), a naturalpathogen of scarab beetle larvae (Coleoptera: Scarabaeidae) from New Jersey. Nematology.

Tashiro, H. 1987.Turfgrass insects of the United States and Canada. 2003; Cornell University Press, Ithaca, NY.

Theobald, F.V., 1911. The vine weevil (Otiorhynchus sulcatus Fabr.). Journal of the Southeastern Agricultural College, Wye, Economic Zoology Report 20, 136.

Schroder, D., 1974. Untersuchungen tiber die Aussichteneiner biologischen Bekampfung von possibilities of biological control of elm bark beetles (Scolytidae) with the view of reduction of the dutch elm disease. (Ger., eng. summ.). Z. Angew. Ent. 76(2), 150-159. Scolytiden an Ulmen als Mittel zur Einschrankung des "Ulmensterbens".

Schmid, J.M., 1970. Enoclerus sphegeus (Coleoptera: Cleridae), a predator of Dendroctonus Ponderosae (Coleoptera: Scolytidae) in the Black Hills. Canadian Entomolgy 102(8), 969-977.

Sekar, V., 1987. The insecticidal crystal protein gene is expressed in vegetative cells of Bacillus thuringiensis var. tenebrionis. Current Microbiology 17, 347-349.

Shankarnarayan, C., Somashekhar, N., Singaravelu, E., 2006. Biocontrol potential of entomopathogenic nematodes Heterorhabditis and Steinernema against pupae and adults of white grubHolotrichia serrata $F$. Sugar Tech. $20068,268-371$.

Shukla, R.P., Tandon, P.L., Singh, S.J., 1984. Baculovirus a new pathogen of mango nut weevil Sternochetus mangiferae (F.) (Coleoptera: Curculionidae). Current Sciences 53, 593-594.

Smith, F.F., 1932. Biology and control of the black vine weevil. United States Department of Agriculture Technical Bulletin No. 325.

Stack, C.M., Easwarmoorthy, S., Mehta, U.K., Downes, M.J., Griffin, C.T., Bumell, A.M., 2000. Molecular characterization of Heterorhabditis indica isolates from India, Kenya, Indonesia and Cuba, Nemat 2, 477-487.

Stallcup, P.L., 1963. A method for investigating avian predation on the adult Black Hills beetle. MSc Thesis, Colorado State Univ., Fort Collins, 60.

Struble, G.R., 1942. Laboratory propagation of two predators of the mountain pine beetle. Journal of Economic Entomolgy 35(6), 841-844.

Sun, M., Zhang, L., Yu, Z.N., 2003. Molecular biology of Bacillus thuriengiensis. In. Upadhyay, R.K., Advances in microbial control of insect pest. Kluwer Academic/ Plenum Publishers, 2003, New York, USA.

Tan, Y.C., 1992. The prevention and control of pests and pathogens in hybrid rice: Chinese Agricultural Science and Technology Press, Beijing, China 79-85.

Van Frankenhuyzen, K., 2009. Insecticidal activity of Bacillus thuringiensis crystal proteins. Journal of Invertebrate Pathology 101, 1-16.

Weiser, J., 1963. Uber Massenzuchten von Pyemotes Milben. On mass rearing of Pyemotes mites. (Ger.) Beitr. Entomologia 13(3/4), 547-551.

Wichmann, H.E., 1957. Untersuchungen, ilber Ipstypographus L. und seine Umwelt. Die Kamelhalsfliegen. [Investigations on Ips typographus L. and its environment. Snakeflies.I (Ger., eng. summ.). Z. Angew. Ent 40, 433-440.

Wright, J.E., 1993.Control of the boll weevil (Coleoptera: Curculionidae) with Naturalist-L: a mycoinsecticide. Journal of Economic Entomology 86, 1355-1358.

Yokoyama, T.M., Hasegawa, A., Fujiie, M., Sawada,K., Noguchi, 1998. Microbial control of scarab beetle larvae by a formulation of Metarhizium anisopliae (Deuteromycotina:Hyphomycetes) in a sweet potato field. Applied Entomology and Zoology 33, 215-218.

Yu, Z.N., 1990. Bacillus thuringiensis. Science Press, Beijing, China. 113. Yu, Z.N., 2000. Microbial pesticides and its industrialization. Journal of Biological control Science Press, Beijing, China.

Zelazny, B., 1976. Transmission of a baculovirus in populations of Oryctes rhinoceros. Journal of Invertibrate Pathology 27, 221-227.

Zelazny, B., Alfiler, A.R., Crawford, A.M., 1987. Preparation of baculovirus inoculum for use by coconut farmers to control rhinoceros beetle (Oryctesrhinoceros ). FAO Plant Protection Bull35, 36-42.

Zelazny, B., Avtar, M.L., Rajendra, S., Malone, L.A., 1998. Papuana uninodis, a new host for the baculovirus of Oryctes. Journal of Invertibrate Pathology 51, 157.

Zhang, H.Y., Deng, W.X., 1998. The screening of typical coleopteran pests measured biologically using Bacillus thuringiensis preparation. Hubei Agricultural Science 2, 4. 